\title{
Interception Practices in Europe and Their Implications
}

\author{
Areti Sianni
}

\begin{abstract}
The dilemma of reconciling migration control functions and State obligations for refugee protection has underlined much of the immigration and asylum debate in the European Union. In recent years, numerous measures have been introduced to block access to refugee status determination. This paper focuses on EU policies of non-entrée as they relate to the interception of individuals en route to Europe. It argues that there is a fundamental imbalance in the Union's activities relating to asylum and migration management with recent measures having the effect of undermining the right to seek asylum and effectively blocking access to protection.
\end{abstract}

\section{Résumé}

Les débats au sein de l'Union européenne sur les questions de l'immigration et du droit d'asile ont été marqués par la problématique de comment réconcilier les fonctions de contrôle de l'immigration et les obligations de l'état en matière de protection des réfugiés. De nombreuses mesures ont été adoptées au cours des dernières années pour bloquer l'accès au processus de détermination $d u$ droit d'asile. Cet article examine les politiques de non entrée de l'Union Européenne, tout spécialement en relation avec la pratique d'interception d'individus en route pour l'Europe. L'article soutient que les activités de l'Union Européenne en matière de gestion de la question de l'immigration et du droit d'asile souffrent d'un déséquilibre fondamental, et que les mesures récentes ont eu pour conséquence d'affaiblir le droit d'asile et d'interdire l'accès à la protection.

\section{Interception in Europe}

7 he dilemma of reconciling migration control functions and State obligations for the protection of refugees has underlined much of the debate on immigration and asylum policy in the European Union. In recent years, numerous measures have been introduced to block access to refugee status determination. These have included mechanisms that operate as barriers, either preventing asylum seekers from access to the territory of a European country where they could seek and find protection, or, alternatively, for those who manage to reach the shores of potential asylum states, applying admissibility criteria which allow states to deport them without offering an effective possibility of having their asylum applications examined in substance. This paper will focus on the policies of non-entrée or non-arrival as they relate to the interception of individuals en route to Europe.

Interception has been defined by UNHCR as "encompassing all measures applied by a State outside its national territory in order to prevent, interrupt or stop the movement of persons without the required documentation crossing international borders by land, air or sea and making their way to the country of prospective destination." ${ }^{.1}$ In the context of the European Union, interception practices need to be considered within the broader process of harmonization of asylum and immigration measures. In this process, the management of migration flows has been seen as "one of the three essential elements together with cooperation with countries of origin and the integration of legal immigrants for a comprehensive and therefore effective immigration policy."

In October 1999, the European Council held a special meeting in Tampere, Finland, on the establishment of an area of freedom, security, and justice. There, EU heads of state committed the Union "to develop(ing) common poli- 
cies on asylum and immigration while taking into account the need for a consistent control of external borders to stop illegal immigration and to combat those who organise it and commit related international crimes." In fighting illegal immigration, the special meeting concluded that "common policies must be based on principles which are both clear to our own citizens and also offer guarantees to those who seek protection in or access to the European Union." ${ }^{3}$ NGOs at the time welcomed the formulation of this paragraph as an affirmation of the Union's commitment to ensuring a balanced approach which allowed for full compliance with the absolute respect of the right to seek asylum when introducing immigration control measures. ${ }^{4}$

The importance of a balanced approach in the fight against illegal immigration was reiterated in the November 2001 Commission Communication on a Common Policy on Illegal Immigration 5 and the "Proposal for a Comprehensive Plan to Combat Illegal Immigration and Trafficking of Human Beings in the European Union," approved by the Justice and Home Affairs Council on 28 February $2002 .^{6}$ Both documents provide that "measures relating to the fight against illegal immigration have to balance the right to decide whether to accord or refuse admission to the territory to third country nationals and the obligation to protect those genuinely in need of international protection." In doing so, Member States were called upon to "explore possibilities of offering rapid access to protection so that refugees do not need to resort to illegal immigration or people smugglers." 7

Notwithstanding these affirmations, an overview of EU policy debate and initiatives in recent years would highlight the absence of a real balance in the activities of the Union in relation to asylum and migration management. This is evident in the Conclusions of the European Council meeting in Laeken in December 2001, set up to assess the progress in the two years since Tampere. ${ }^{8}$ It is also clear in the Conclusions of the Seville European Council meeting which, beyond a timetable for agreeing upon the asylum measures under discussion, mostly limited itself to reaching consensus on border control enforcement measures, the conclusion of readmission agreements, and the evaluation of agreements with host and transit countries to promote co-operation in the fight against illegal immigration. ${ }^{9}$ With deterrence rather than protection being the key priority for most EU Member States, a range of measures has been put in place that has had the effect of undermining the right to seek asylum and effectively blocking access to Europe. The following sections will consider some of these measures in turn and will conclude by setting out some of their implications.

\section{A. Visa Policies}

On 15 March 2001, a Council Regulation was adopted listing third countries whose nationals must be in possession of visas when crossing the external borders and those whose nationals are exempt from that requirement. ${ }^{10}$ The regulation includes a common list of 131 countries whose nationals must have a visa when entering the territory of the European Union, among them being a considerable number of refugee producing countries such as Afghanistan, Somalia, Sudan, and Iraq. A visa policy is a legitimate tool for controlling immigration. When, however, it is aimed at blocking access to protection of persons fleeing persecution and grave human rights violations, it is in flagrant contradiction of the institution of asylum and international human rights and refugee norms. At the time of the Seville meeting in May 2002, the European Council called for a review of the list of third countries whose nationals require visas or are exempt from that requirement. ${ }^{11}$ In responding, NGOs asked for the introduction of exemptions from visa requirements for persons fleeing countries suffering civil wars or systematic abuses of human rights in order to enable them to gain access to Europe legally. ${ }^{12}$ Although this was not taken up by Member States in the recent review of the regulation on visas in March $2003,{ }^{13}$ it is encouraging that some of the current debate is shifting towards the development of an EU system of "protected entry procedures." This term describes arrangements that would allow non-nationals "to approach the potential host state outside its territory with a claim for asylum or other forms of international protection and to be granted an entry permit in case of a positive response to that claim, be it preliminary or final." 14 Such arrangements already exist in some Member States on a formalized basis ${ }^{15}$ while some other Member States allow access through informal measures on an exceptional basis. ${ }^{16}$

In this context, a recent European Commission publication, Study on the Feasibility of Processing Asylum Claims outside the EU against the Background of the Common European Asylum System and the Goal of a Common Asylum Procedure, has identified five proposals which Member States could consider when developing protected entry procedures in the future, ranging from a flexible use of the visa regime to the introduction of a sponsorship model, the development of an EU Regional Task Force and EU Regional Nodes, gradual harmonization through a Directive based on best practices, and the development of a Schengen Asylum Visa. ${ }^{17}$ Out of these proposals, two have been singled out by the Commission for further exploration relating to the viability of setting up an EU regional presence "to provide expertise to local authorities where needed and operate a referral system, matching different needs with appropriate solutions" and the gradual harmonization 
through a Directive based upon best practices of protected entry procedures. ${ }^{18}$ In light of the difficulties and hardship facing refugees seeking access to Europe, any proposals that aim at increasing the options for people to obtain legal access to protection are to be welcome. The focus, however, needs to remain on facilitating access to protection for those in need of international protection. Here, in the light of the emphasis placed by some EU Member States on the orderly and managed arrival of refugees, a risk exists that the availability of protected entry systems might be used as the justification for prejudicing the treatment of asylum claims of persons arriving spontaneously in Europe. ${ }^{19}$

\section{B. Carrier Sanctions}

Strict visa policies operate in conjunction with sanctions imposed on transport carriers for bringing into the territory of Member States passengers who are not in possession of travel documents and visas required by national or international regulations. An EU Directive on carrier sanctions was formally adopted on 28 June 2001, supplementing the provisions of Article 26 of the Schengen Convention. ${ }^{20}$ This lays down the obligations of carriers transporting foreign nationals into the territory of EU Member States and provides for the harmonization of financial penalties in cases where carriers fail to comply with its provisions. ${ }^{21}$ Beyond the obligations of the Schengen Convention, carriers are now expected to assume responsibility for returning third-country nationals in transit if they have been refused entry to the State of destination and have been sent back to the transit country, or if the carrier that was to take them to the country of destination refuses to allow them to board..$^{22}$ They are also responsible for immediately finding means of onward transportation in the cases where they are unable to effect the return of third-country nationals whose entry has been refused and for bearing any related costs including the cost of staying in the country until return can be effected. ${ }^{23}$ Failure to engage in the exercise of immigration control functions risks penalties of 3000 euros minimum for each person carried. ${ }^{24}$

In UNHCR's opinion, carrier sanctions "should only be implemented in a manner consistent with refugee protection principles and should be accompanied by appropriate safeguards so as not to hinder access to status determination procedures by persons in need of protection." Sanctions should be enforced only in the event of negligence in checking documents; if the person is admitted to the asylum procedure, carriers should be exempted from liability. ${ }^{25}$ The weakest of safeguards are included in the EU Directive on carrier sanctions. Despite affirming that its application is without prejudice to obligations resulting from the Refugee Convention, the Directive provides no safeguards to ensure protection from refoulement of persons for whom carriers are unable to effect return and for whom carriers are therefore obliged to arrange onward transportation. Nor does the Directive provide for any access to remedies for asylum seekers who have been refused permission to board a plane or are being forced to return or be transported to a country where they might face violations of their rights in the sense of Article 33 of the Refugee Convention or Article 3 of the European Convention on Human Rights. With regard to the provisions on financial penalties, although Article 4.2 sets out that these are "without prejudice to Member States' obligations in cases where a third country national seeks international protection," there is no express requirement for Member States to exempt airlines from paying penalties if "the third country national is admitted to the territory for asylum purposes." 26 This was a formulation that was included in the original proposal for a Council Directive on carriers sanctions in recognition of the reality of refugee flight to safety which at times involves the use of forged documents. It was subsequently upheld in the report on the proposal by the European Parliament's Committee on Citizens' Freedoms and Rights, Justice and Home Affairs. There, a call was made for an exception from penalties if "a third-country national seeks asylum immediately after arriving on the territory of the State of destination; the person is granted refugee status or leave to remain under a subsidiary form of protection (or) the person is admitted to the asylum determination procedure." ${ }^{27}$ Regrettably, the original formulation was rejected on the basis of Germany's objections that it "could make penalties for carriers ineffective and increase asylum applications," ${ }^{28}$ a position reiterated by the Irish Minister for Justice during negotiations of carrier-sanctions-related provisions of the Irish Immigration Bill in early 2003.

Faced with increased obligations and the threat of substantial financial penalties and associated costs, carriers have introduced extensive checking facilities at airports as well as major ports of entry to the European Union, the result being the privatization of government immigration control functions. Rather than trained government officials exercising their functions under effective judicial control and in line with their government's obligations under international law, the responsibility of screening refugees has been delegated to transport companies and their personnel who are untrained in refugee and human rights law and ill-positioned to undertake any asylum determination functions, but also unaccountable for their actions under international law. The carrier industry, concerned mostly about escalating costs, has sought to challenge the legal framework in certain cases. In Sweden, despite the deadline of 11 February 2003 for transposition of the Directive on 
carrier sanctions into national legislation, the government, expecting that it will not secure the necessary majority in Parliament, has yet to introduce amendments to the Swedish Aliens Act that would allow it to impose financial penalties on airlines. SAS, the Swedish national carrier, commenting on the Ministry for Foreign Affairs' memorandum on carriers' responsibility in the Aliens Act, has expressed strong opposition against airlines engaging in assessing which passengers have valid reasons to seek asylum, arguing that "this assessment requires a considerable amount of time for the concerned authorities and results in a careful investigation. The flight company on the other hand, has about a minute during check in to make a similar judgement for each individual person." 29 The company further objected to laying down general guidelines for airport staff in order to block certain types of "suspect" passengers on the basis that this might seem discriminatory.

In Austria, a November 2002 ruling by a court of appeal of the Land of Lower Austria has overturned a decision reached in the first instance to fine an airline a total of 36,000 euros for transporting twelve insufficiently documented passengers to Austria. The judgment considered that carriers could not be expected to detect forged travel documents, as they were often difficult to distinguish from genuine ones. ${ }^{30}$ This follows a landmark decision by the Austrian Constitutional Court in October 2001 which declared relevant provisions of the 1997 Austrian Aliens Act null and void on the basis that they did not specify exactly what kind of obligations carriers are obliged to fulfill when transporting passengers to Austria nor whether, or how, in fulfilling their obligations carriers needed to take into consideration Austrian commitments under the Refugee Convention. $^{31}$

In Britain, a High Court judge ruled in December 2001 that holding lorry drivers responsible for transporting stowaways is "unworkable in practice and unfair in law"

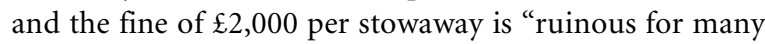
persons of ordinary means" and could amount to violations of the European Convention on Human Rights (Article 6 on the right to a fair trial and Article 1, Protocol No. 1, on the protection of property) since a driver risks having his vehicle confiscated if he cannot pay the fine immediately. ${ }^{32}$ This ruling was partially upheld at a Court of Appeal decision in February 2002 which led to changes in legislation on carriers' liability. ${ }^{33}$ Under the new law authorities are required to take into account efforts made by lorry drivers to prevent their vehicles from being misused by irregular migrants when determining fines for abuse.

\section{Externalization of Immigration Controls}

Complementing the objectives of carrier sanctions provisions, there has been an increase in recent years in the use of other measures aimed at externalizing immigration controls. These have taken the form of posting immigration officers at diplomatic missions in countries from which EU Member States want to reduce population movements towards their borders. They have also involved the placement of immigration and airline liaison officers at major international airports and seaports in countries of origin and transit, with the task of assisting carriers and national authorities to prevent the embarkation of undocumented and improperly documented travellers. This is not a new phenomenon. Some EU Member States have operated for some years a system of stationing immigration officers in third countries whose airports are considered to be starting or transfer points for illegal immigration. The Netherlands for example, operates a network of Immigration Liaison Officers (ILOs) which in 2001 consisted of nine officers in nine countries. ${ }^{34}$ During the same year, the UK had similar arrangements in

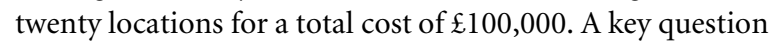
in relation to these arrangements has concerned the treatment by officials responsible for externalized immigration controls of persons fleeing persecution who might not be in a position to comply with immigration formalities. Here, the risk is that access to protection could be denied by Member States acting in co-operation with the actual country from which international protection is being sought.

In addition to the stationing of liaison officers who operate in an advisory capacity, since 1999, the UK has introduced legislative provisions that allow for immigration rules to be operated extraterritorially and not only at British ports of entry. On 18 July 2001, the UK in agreement with the Czech Republic started a scheme at Prague Airport of pre-entry clearance immigration controls. This aimed principally at putting an end to the arrival of asylum seekers from the Czech Republic, the vast majority of whom were of Romani ethnic origin (Roma). The scheme has been proven effective as a migration control tool. ${ }^{35}$ Its compliance with the UK's obligations under refugee and human rights law, however, has been questioned. In a submission on behalf of UNHCR to a British Court of Appeal dealing with a case brought against the Home Secretary by the European Roma Rights Centre and six Romani nationals, the scheme was described as having "frustrate(d) the object and purpose of the 1951 Convention contrary to the international legal principle of good faith...(and) rendered the 1951 Convention nugatory (as) it prevents provisions such as Article 31 or 33 ever being engaged." ${ }^{36}$ The scheme's compliance with anti-discrimination provisions has also been questioned, given its focus on persons of Romani 
origin. ${ }^{37}$ Beyond the Prague practice, under a specific agreement between France and the UK, British immigration officers now have the power to also exercise full immigration controls on passengers on Eurostar trains and those embarking in French ports. In accordance with the 2002 National Immigration and Asylum Act, this power has been extended to any port in the European Economic Area. ${ }^{38}$

At Community level, following the Seville Presidency Conclusions, which call for implementation before the end of 2002, a process has been underway for the development of an EU network of Member States' Immigration Liaison Officers (ILOs). ${ }^{39}$ This will be based upon experiences of previous joint projects run by individual Member States such as the UK and Italy joint initiative on southeastern Europe (in operation since 2001) ) $^{40}$ and the Belgian-led western Balkans ILO network (since December 2002). Under this scheme, still under negotiation, it is proposed that representatives of Member States will be posted at national consular authorities of Member States in third countries, relevant authorities of other Member States or competent authorities of third countries, with a view to contributing to the prevention and combating of illegal immigration, the return of illegal immigrants, and the management of legal migration. Member States' officers will be expected to maintain direct contacts with the competent authorities in the host country and any appropriate organization within the host country. They will also be expected to constitute local and regional co-operation networks for the purpose, inter alia, of exchanging information, coordinating positions to be adopted with commercial carriers, and adopting common approaches to the methods of collecting and reporting strategically relevant information, including risk analyses. ${ }^{41} \mathrm{~A}$ report of their activities as well as the situation in the host country will be submitted to the Council and the Commission by the Member State holding the presidency or serving as acting presidency by the end of each semester. ${ }^{42}$

The inclusion of a provision for an activities' report of the proposed ILO network might be an important step towards ensuring transparency and overcoming the secrecy characterizing the operations of national ILO arrangements to date. What is needed, moreover, is the adoption of a common approach among Member States' immigration or airline liaison officers as to the procedure for dealing with cases that might come under the scope of the Refugee Convention or other relevant human rights instruments. Such an approach should tacitly acknowledge the realities of refugee flight which frequently involve reliance upon forged documents and be in full compliance with Article 31 of the Refugee Convention.

\section{Interception in the Context of EU's External Relations}

An area that has been a focus of intensified activity by the European Union and Member States relates to co-operation with third countries in the management of migration flows. In late 1998, in an attempt to integrate asylum and immigration concerns into all areas of EU external policy, the High Level Working Group on Migration and Asylum (HLWG) was established with the task of preparing crosspillar action plans for the countries of origin and transit of asylum seekers and migrants. The task of this Group until 2002 was to design EU Action Plans and develop practical and operational proposals to increase co-operation with countries of origin and transit that enhanced the capacity of the EU to manage migration flows. Six regions or countries were identified, including Afghanistan and the neighbouring region, Morocco, Somalia, Sri Lanka, Iraq, and Albania and the neighbouring region. Action Plans on these countries/regions were submitted to the European Council in Tampere which agreed on the continuation of the HLWG's mandate and called for a "comprehensive approach to migration addressing political, human rights and development issues in countries and regions of origin and transit." 43

The first phase of the implementation of the HLWG Action Plans was characterized by an "impression of imbalance," a rather euphemistic term for describing an exclusive focus on migration controls. ${ }^{44}$ A report evaluating the work of the Group, prepared for the Nice European Council meeting in December 2000, underlined that "countries in which the plans are directed feel that they are the target of unilateral policy by the Union focusing on repressive action." ${ }^{45}$ It stated that "the actual implementation of the plans respects the balance originally sought between the various areas (foreign policy, development, asylum and migration)," arguing that "it would be detrimental to the credibility of this new European Union policy to allow one aspect to predominate owing to difficulties in implementation." 46

A new momentum in the integration of immigration policy into the European Union's relations with third countries can be found since the meeting of EU Heads of State in Seville on 21-22 June 2002.47 The Seville European Council urged that "any future cooperation, association or equivalent agreement which the European Union concludes with any country should include a clause on joint management of migration flows and on compulsory readmission in the event of illegal immigration." The Council further reaffirmed the necessity of carrying out a systematic assessment of relations with third countries which do not co-operate in combating illegal immigration, concluding that "inadequate cooperation by a country could hamper the establishment of closer relations between that country and the European Union." 
Following Seville, a set of criteria has been developed to identify countries of origin and transit of particular interest. ${ }^{48}$ So far, nine countries have been selected for the purpose of intensified co-operation including: Albania, China, Morocco, Russia, Ukraine, Tunisia, Federal Republic of Yugoslavia, Libya, and Turkey. ${ }^{49}$ Co-operation with them is seen as not only desirable but also essential given that they represent key source and transit countries for irregular migration. Further, plans are underway to include a clause on joint management of migration flows and compulsory readmission in future Community agreements with, for example, Syria, Iran, Mercosur, and the Andean Community. ${ }^{50}$

What can be made of the plethora of initiatives on cooperation in the management of migration flows with third countries and their impact on the right to seek and enjoy asylum? The establishment of the High Level Working Group was originally seen as "a potentially important step towards a more comprehensive, EU cross-pillar approach to migration and asylum policy." ${ }^{11}$ Warning against the Group's work solely focusing on illegal immigration to the European Union, measures were called for co-operation to address the root causes of forced and voluntary migration, including poverty reduction, protection of human rights, and promotion of democratic institutions. Nevertheless, an overview of the activities of the High Level Working Group and the Union's initiatives following the Seville Conclusions highlights a clear emphasis on measures to fight illegal immigration which compares poorly with the level of attention paid to the root causes of refugee flight and to measures to improve refugee protection. The November 2002 General Affairs Council Conclusions illustrate this point. They identify a set of parameters for "all existing or future comprehensive dialogues pursued... (which) should where relevant, include subjects such as return, readmission and documentation, implementation of agreements on management of migration flows, preventive policies and technical assistance geared towards institutional capacity building" ${ }^{52}$ No reference is made here to strengthening the rule of law or building institutional capacity to safeguard human rights and provide for effective refugee protection. This is also the case in the Commission's Communication on Integrating Migration Issues in the European Union's Relations with Third Countries. ${ }^{53}$ Commenting on the limited focus of the document's conclusions on return policies and border controls, a number of NGOs expressed concern about the potential risk of the fight against irregular migration extending "beyond overshadowing the international protection regime to also taking hostage of the development sector." 54

Examples of actions approved in relation to some of the countries selected for intensified co-operation show a clear focus on control measures. In the case of Morocco, a program to combat illegal immigration by supporting improvements to the management of border checks has been adopted for the period 2002-04 with a budget of 40 million euros. The money will be used to improve surveillance measures on Moroccan sea and land borders and to set up an information centre to advise potential candidates of illegal immigration on how to seek entry into the EU by legal means. Likewise, negotiations are currently underway upon the request of the Italian government for the EU to ease restrictions on the purchase of military equipment by Libya so that it can increase its coast guard capacity to prevent the clandestine departure of vessels carrying irregular migrants to Europe. Further, within the framework of plans to create a "friendly neighbourhood with whom the EU enjoys close, peaceful and co-operative relations" the EU intends, inter alia, to assist neighbouring countries in reinforcing their efforts to combat illegal migration and to establish mechanisms for returns, especially in relation to illegal transit migration. ${ }^{55}$

Against a backdrop of control-oriented measures, the absence of a concrete commitment for Community action to address the human rights abuses, organized violence, and conflict that are the main causes for involuntary migration becomes apparent. So is the absence of any measures that engage the Union and its Member States in meaningful responsibility sharing with first countries of asylum in regions of origin where the majority of refugees are located. ${ }^{56}$ Rather, responsibility shifting seems to be the name of the game. Faced with no options of protection, many individual refugees take risks in the hands of smugglers and traffickers: the result is a rise in human suffering at the borders of Europe.

\section{Europe's Reality: The Implications of Interception Measures for Refugee Protection}

What has been the cumulative effect on refugee protection of visa policies, sanctions, and pressure on countries of transit to co-operate in the fight against illegal immigration? In a few words, the de facto criminalization of the act of seeking asylum. Without any other option, people in need of international protection are forced to rely on smugglers and traffickers who can often provide the only viable means of entry into Europe. The absence of hard data on trafficking and smuggling makes it difficult to quantify the extent of the problem across the European Union. ${ }^{57}$ Some ad hoc statistics are, however, illustrative. In 2002, for example, 16,504 boat migrants were apprehended for trying to reach Spain illegally by sea, an average of forty-six people per day. During the same period, thirty-five bodies were discovered at sea; this figure concerns the number of bodies found in Spanish 
territorial waters and not those who drowned while attempting to reach Spain by sea. Similarly, 3,766 stowaways were found in lorries and containers crossing to the UK from Belgian ports, an increase of 40 per cent from figures in 1999. As the costs in terms of human suffering increase, the physical barriers to entry to Europe have become higher and methods of interception more sophisticated. During, for example, the last six months of 2002, seventeen joint operations, pilot projects, and ad hoc centres of illegal migration were approved under intriguing names such as Ulysses, ${ }^{58}$ Triton, ${ }^{59}$ Orca, ${ }^{60}$ RIO IV, ${ }^{61}$ and Project Deniz. ${ }^{62}$

More recently, in February 2003, the UK government proposed the establishment of protected zones in third countries to which those arriving in EU Member States and claiming asylum could be transferred to have their claims processed. Such centres might be on transit routes into the EU and might "also receive illegal migrants intercepted en route to the EU before they had lodged an asylum claim but where they had a clear intention of doing so." ${ }^{63}$ The UK proposals have been strongly opposed by British and international NGOs as "unlawful, unworkable and unprincipled" and as an attempt to undermine the rights-based global refugee protection regime. ${ }^{64}$ They have also been seen as an attempt to shift responsibility for hosting refugees to poorer countries, despite the reality that many countries close to regions of origin of refugee populations host far greater numbers of refugees and asylum seekers than do EU Member States. ${ }^{65}$

Although the British government has recently claimed to have moved away from the idea of transit processing centres on the edge of Europe, they plan to move ahead with their plans of regional protection zones. ${ }^{66}$ In doing so, they might work in co-operation with what they have termed "the coalition of the willing," countries such as The Netherlands and Denmark who are interested in exploring ways of providing protection in regions of origin. At the EU level, the Thessaloniki European Council, held in June 2003, has asked that the Commission "explore(s) all parameters in order to ensure more orderly and managed entry in the EU of persons in need of international protection, and to examine ways and means to enhance the protection capacity of regions of origin." A comprehensive report on these issues is expected to be presented before June 2004 suggesting measures including legal implications. Further, the Council's Conclusions acknowledge the importance of developing an evaluation mechanism to monitor relations with third countries which do not co-operate with the EU in combating illegal immigration. Among the topics which are identified to be of primary importance are the efforts of third countries in "border control and interception of illegal immigrants, combating of trafficking in human be- ings... cooperation on visa policy and possible adaptation of visa systems." ${ }^{67}$ The European Commission will be expected to report annually on the results of monitoring co-operation with third countries.

In 1997, EU Member States agreed to the Amsterdam Treaty, thereby committing themselves to the creation of an "area of freedom, security and justice." In undertaking this task, they agreed upon the development of common standards for asylum based on the principles of solidarity and responsibility sharing. Since the Treaty came into force in May 1999, a process has been underway to develop a Common European Asylum System. The development of such a system has been seen as a question of fundamental justice if not of absolute necessity. In this context, the various measures under discussion during the last few years have been considered to have the potential to represent an important step away from the "protection lottery" currently in place in Europe.

There is no doubt that some progress has been made towards the development of common asylum standards. Notwithstanding this, an overview of the range of measures to fight illegal immigration, as compared with progress made in the area of common asylum standards, would indicate the presence of a fundamentally imbalanced approach in the Union's work towards the creation of an area of "freedom, security and justice." Member States have consistently been prepared to agree upon control-related measures while opposing the introduction of any standards which might result in substantial changes in their national asylum systems. Although some potentially positive proposals are under discussion, in particular with regard to the development of an EU resettlement scheme and a harmonized approach on protected entry procedures, the reality on the ground is of persons in need of protection being denied the possibility of legal exit from their countries or regions of origin. In the fight against illegal immigration, the risk remains that EU Member States might find themselves acting in co-operation with the very countries from which refugees might be fleeing. In the search for order and a managed approach, the danger is also one of irrevocably compromising the fundamental right to seek and enjoy asylum in the territory of the European Union.

\section{Notes}

1. Working definition of interception as contained in the UNHCR Note, Interception of Asylum Seekers and Refugees: The International Framework and Recommendations for a Comprehensive Approach (Geneva, EC/50/SC/CRP.17).

2. European Commission, Communication from the Commission to the European Parliament and the Council in view of the European Council of Thessaloniki on the development of a com- 
mon policy on illegal immigration, smuggling and trafficking of human beings, external borders and the return of illegal residents (Brussels: COM/2003/0323 final), Introduction.

3. European Council, Presidency Conclusions (Tampere: European Council, 15-16 October 1999), para. 3.

4. European Council on Refugees and Exiles (ECRE), Observations on the Presidency Conclusions of the Tampere European Council, 15-16 October 1999 (London: ECRE, 1999), para. 7.

5. European Commission, Communication on a Common Policy on Illegal Immigration (Brussels: COM (2001) 672 final, 15.11.2001), para. 3.2.

6. European Commission, "Proposal for a Comprehensive Plan to Combat Illegal Immigration and Trafficking of Human Beings in the European Union," Official Journal of the European Communities, C142/23, (14.6.2002).

7. Ibid. para. 11.

8. European Council, Presidency Conclusions (Laeken: European Council, 14-15 December 2001). Para. 39 of the Conclusions, for example, makes a reference to a common policy on asylum and immigration that "maintain(s) the necessary balance between protection of refugees...the legitimate aspiration to a better life and the reception capacities of the Union and its Member States." Notwithstanding, para. 40 makes no reference to integrating refugee protection and human rights concerns into the EU's policy on migratory flows. Instead, the emphasis here is on migration control measures. See further, ECRE, Observations on the Presidency Conclusions of the European Council Meeting in Laeken (London: December 2001).

9. European Council, Presidency Conclusions (Seville: European Council, 21-22 June 2002), para. 37.

10. Council Regulation (EC) No 539/2001 of 15 March 2001 listing the third countries whose nationals must be in possession of visas when crossing the external borders and those whose nationals are exempt from that requirement, Official Journal of the European Communities, L 81/1, (21.3.2001).

11. Supra note 9, para. 30.

12. ECRE, Observations on the Presidency Conclusions of the Seville European Council Meeting, 21 and 22 June 2002 (London: ECRE, 2002).

13. Council Regulation (EC), No. 453/2003 of 6 March 2003 amending Regulation (EC) No. 539/2001 listing the third countries whose nationals must be in possession of visas when crossing the external borders and those whose nationals are exempt from that requirement, Official Journal of the European Union, L69 Vol. 46, (13.3.2003).

14. G. Noll, J. Fagerlund, and F. Liebaut, Study on the Feasibility of Processing Asylum Claims outside the EU against the Background of the Common European Asylum System and the Goal of a Common Asylum Procedure, (Copenhagen: The Danish Centre for Human Rights, January 2002), 20.

15. Austria, France, The Netherlands, Spain, and the UK. See further, ibid., Chapters 6.1.1, 6.1.2, 6.1.3, 6.1.5, 6.1.6.

16. Belgium, Germany, Ireland, Italy, Luxembourg, and Portugal. 17. Supra note $14,222-250$.
18. European Commission, Communication towards more accessible, equitable and managed asylum systems (Brussels, COM (2003) 315 final, 3.6.2003), para. 6.1.2.3.

19. European Council on Refugees and Exiles and U.S. Committee on Refugees (USCR), Responding to the Asylum and Access Challenge: An Agenda for Comprehensive Engagement in Protracted Refugee Situations (London: ECRE \& USCR, August 2003), section 4.4.2 on embassy procedures and humanitarian visas.

20. Convention implementing the Schengen Agreement of 14 June 1985 between the Governments of the States of the Benelux Economic Union, the Federal Republic of Germany, and the French Republic on the gradual abolition of checks at their common borders.

21. Council Directive 2001/51/EC of 28 June 2001 supplementing the provisions of Article 26 of the Convention implementing the Schengen Agreement of 14 June 1985, Official Journal of the European Communities, L 187/45, (10.7.2001), Preamble.

22. Ibid., Article 2.

23. Article 3.

24. Article 4, 1(b).

25. UNHCR, Asylum Applications and the Entry into Force of the Schengen Implementation Agreement: Some Observations of UNHCR (Geneva: UNHCR, March 1995).

26. Council of the European Union, Draft Council Directive concerning the harmonisation of financial penalties imposed on carriers transporting into the territory of the Member States third-country nationals lacking the documents necessary for admission, 14074/00, Front 67, Comix 868 (Brussels: 29 November 2000), Article 4,3.

27. European Parliament, Report on the initiative of the French Republic for adoption of a Council Directive concerning the harmonisation of penalties imposed on carriers transporting into the territory of the Member States third country nationals lacking the documents necessary for admission (Kirkhope Report), Final A5-0069/2001 (Brussels: European Parliament, 27 February 2001).

28. German Delegation, Comments on the initiative of the French Republic with a view to the adoption of a Council Directive concerning the harmonisation of financial penalties imposed on carriers transporting into the territory of the Member States third country nationals not in possession of the documents necessary for admission, 12361/00, FRONT 53 COMIX 730, (Brussels: 16 October 2000) Part 4.

29. Scandinavian Airlines System, Comments to the Ministry of Foreign Affairs, Department for Migration and Asylum Policies Regarding Department Memorandum on Carriers' Responsibility in the Aliens Act, Legal Department (2001) 74.

30. Migration News Sheet, No. 239/2003-02, (February 2003).

31. Austrian Constitutional Court, G224/01 of 1 October 2001. See also, Caritas Europe, The Case against Carriers' Liabilities (Brussels: Round Table on Carriers' Liability Related to Illegal Immigration, 30 November 2001).

32. High Court of Justice, International Transport Roth GMBH \& others v. the Home Office (5 December 2001). 
33. Court of Appeal Civil Division, Secretary of State for the Home Department vs. International Transport Roth $\mathrm{GmbH}$ and others (22 February 2002).

34. E. Beugels, Keynote Presentation (Brussels: Round Table on Carriers' Liability Related to Illegal Immigration, 30 November 2001).

35. The checks are periodic and can last for a number of days. In the three weeks before the start of the operation in May 2001, there were over 200 asylum claims (including dependants) at UK ports from the Czech Republic. Only some twenty such claims were made in the first three weeks following its introduction; over 110 intending travellers from Prague were refused leave to enter the UK during that period. In May 2002, checks resulted in denials of the right to board flights to the UK for forty-seven people.

36. G. Goodwin-Gill, Submission on behalf of UNHCR to the Court of Appeal considering the case of the European Roma Rights Centre and Others v. the Immigration Officer at Prague Airport and the Secretary of State for the Home Department, Case No: C1/2002/2183/QBACF, paras. 14, 29. The case was dismissed at first instance (8 October 2002) and at appeal level (June 2003).

37. Ibid.

38. Refugee Council, Response to the Home Office Consultation on Juxtaposed Controls Implementation, Dover-Calais (London: November 2002).

39. Supra note 9, para. 32 .

40. This aimed at sending immigration officers to countries of origin and transit to train local officials and gather intelligence on trafficking and smuggling networks. See also UK Delegation, Paper on Illegal Immigration via the Western Balkan Route, 5496/01, CIREFI 3, (19 January 2001).

41. Council of the European Union, Initiative of the Hellenic Republic with a view to adopting a Council Regulation on the creation of an immigration liaison officers' network, CIREFI 26 FRONT 81 COMIX 394 (Brussels: 18 June 2003).

42. Ibid, Article 7.

43. Supra note 3, para. 11.

44. High Level Working Group on Asylum and Migration, Report to the European Council in Nice, 13993/00 JAI 152, AG 76 (Brussels: 29 November 2000), para. 53.

45. Ibid.

46. Ibid., para. 54 .

47. Prior to that meeting, the terms of reference of the High Level Working Group were revised to include the development of "a strategic approach and a coherent and integrated policy of the European Union for the most important countries and regions of origin and transit of asylum seekers and refugees without geographical limitation." See Permanent Representatives Committee, Modification of the terms of reference of the High Level Working Group on Asylum and Migration, 9433/02, JAI 109, AG 20, ASIM 18 (Brussels: 2002).

48. General Affairs Council Meeting, Conclusions (Brussels: $2,463^{\text {rd }}$ Council meeting, 18 November 2002). These include "the nature and size of migratory flows towards the EU; geo- graphical position in relation to the EU; need for capacity building concerning migration management; existing framework for cooperation; and attitude towards cooperation on migration issues."

49. Justice and Home Affairs Council Meeting, Conclusions (Brussels: $2,469^{\text {th }}$ Council meeting, 28-29 November 2002), Chapter on Integration of Immigration Policy into the Union's Relations with Third Countries.

50. Council of the European Union, Road Map for the Follow-up to the Conclusions of the European Council in Seville, 6023/4/03 (Brussels: 5 May 2003).

51. ECRE, Observations on the Work of the High Level Working Group on Asylum and Migration (London: 1 June 1999). See also Amnesty International, Comments on the Implementation of the Action Plans adopted by the High Level Working Group on Asylum and Migration (Brussels: September 1999).

52. General Affairs Council, Conclusions (Brussels: $2,463^{\text {rd }}$ Council meeting, 18 November 2002), paras. 3, 7, on external relations and justice and home affairs.

53. European Commission, Communication on Integrating Migration Issues in the European Union's Relations with Third Countries (Brussels: (COM 2002), 703 Final, 3.12.2002).

54. Preliminary Observations by NGOs active in the migration, refugee protection and development field on the European Commission's Communication on "Integrating Migration Issues in the European Union's Relations with Third Countries, COM (2002) 703 final of 3 December 2002 (Brussels: March 2003).

55. European Commission, Communication on Wider Europe Neighbourhood: A New Framework for Relations with Our Eastern and Southern Neighbours, COM (2003) 104 final (Brussels: 11.3. 2003).

56. On the question of responsibility sharing, the Council has invited the European Commission to develop concrete proposals before the end of 2004 on the "refugee burden issue." See Council of the European Union, Draft Council Conclusions on migration and development, DEVGN 15, RELEX 47, JAI 34, ASIM 8 (Brussels: 7 February 2003).

57. See also J. Morrison \& B. Crossland, "The Trafficking and Smuggling of Refugees: The End Game in European Asylum Policy," Working Paper No. 39, New Issues in Refugee Research (Geneva: UNHCR, April 2001).

58. Operation led by Spain in co-operation with France, Italy, Portugal, and the United Kingdom with the aim of enforcing sea border controls off the coasts of the northern Mediterranean and Canary islands.

59. Project led by Greece in co-operation with France, Italy, and Spain. It took place in March 2003 involving joint sea border controls in the southeastern Mediterranean.

60. Project led by Norway with Finland, Germany, Netherlands, Sweden, Estonia, and Poland as observers. The operation's objective is the prevention of illegal immigration/transborder crime and illegal use of visas and documents issued to seamen by improving co-operation between border control authorities. 
61. Led by Spain, the aim of the operation is to improve border control systems and practices in designated ports in EU candidate countries.

62. This involves the secondment of experts to Turkey to combat trafficking of illegal immigrants by sea.

63. New International Approaches to Asylum Processing and Protection, paper submitted by PM Tony Blair to PM Simitis in advance of the Brussels European Council (10 March 2003).

64. Human Rights Watch, An Unjust Vision for Europe's Refugees: Commentary on the U.K 'New Vision' Proposals for the Establishment of Refugee Processing Centres Abroad (17 June 2003); G. Noll, Visions of the Exceptional: Legal and Theoretical Issues Raised by Transit Processing Centres and Protection Zones, (May 2003) [unpublished paper]; Amnesty International, Unlawful and Unworkable - Extra Territorial Processing of Asylum Claims (18 June 2003); Refugee Council, Unsafe havens, unworkable solutions - UK proposals for transit processing centres for refugees and regional management of asylum (May 2003); R. Marx, International protection and reception in the region: The specific European understanding of the principle of international co-operation (4 August 2003).

65. The proposals do not enjoy the support of the majority of EU Member States with the exception of The Netherlands, Denmark, and Austria.

66. Response by Beverly Hughes, Minister of State for the Home Office, to UK NGO letter regarding the proposals on zones of protection (August 2003).

67. European Council, Presidency Conclusions (Thessaloniki: 19-20 June 2003).

Areti Sianni worked as a Policy Officer for the European Council on Refugees and Exiles (ECRE) from December 1997 to October 2003. From May 2002 to May 2003, she was ECRE's Head of Policy and Advocacy. The views expressed in this article do not represent ECRE views on this issue.

(C) Areti Sianni, 2003. This open-access work is licensed under a Creative Commons Attribution-NonCommercial 4.0 International License, which permits use, reproduction and distribution in any medium for non-commercial purposes, provided the original author(s) are credited and the original publication in Refuge: Canada's Journal on Refugees is cited. 